\title{
STUDIES ON THE MECHANISM OF THE INCREASED OXYGEN CONSUMPTION IN PATIENTS WITH CARDIAC DISEASE
}

\author{
BY HARRY RESNIK, JR, AND BEN FRIEDMAN \\ (From the Department of Medicine, Vanderbilt University School of Medicine, Nashrille)
}

(Received for publication April 18, 1935)

Since the introduction of accurate methods for measuring oxygen consumption, that function has been repeatedly observed to be increased in persons with congestive heart failure $(1,2,3,4)$ and to decline as improvement occurs (4). The mechanisms underlying these changes have not been clearly defined. In studying a group of patients with heart failure we were impressed with the constancy and magnitude of the alterations in metabolic rate and attempted to identify some of the factors responsible for them.

This group of patients consisted of individuals with heart disease due to hypertension, syphilis or rheumatic infection. Most of the patients were moderately decompensated, a few had severe failure and a smaller number were without congestive phenomena or had symptoms due to neuroses. The usual measures used in treating heart failure were employed, i.e., rest, sedation, digitalis, diuretics and limitation of fluids. Venesection, thoracentesis and abdominal tapping were resorted to as occasion demanded. Observations were made at frequent intervals under the usual "basal" conditions with the patient sitting in a wheel chair. The oxygen consumption was measured by gas analysis of the expired air, duplicate determinations being made as a rule. The metabolic rates were calculated on the basis of the edema-free weight, using the Boothby and Sandiford modification of DuBois' standard tables (16). In order to minimize the factor of nervousness and apprehension the subjects were trained for one or. two days prior to the beginning of the observations.

Twenty-five patients were studied. They have been classified in three groups, depending on the response to treatment. Group I consists of 13 individuals who showed marked improvement as evidenced by three criteria, i.e., a loss of weight of at least 5 pounds, an increase in vital capacity of 10 per cent or more and the disappearance of paroxysmal dyspnea. Most of the subjects in this group had moderate or advanced congestive failure at the beginning of the observations. In Group II are six persons who claimed subjective relief but in whom the objective evidences of improvement, although demonstrable, were not sufficient to meet the standards for Group I. In general, the patients in this group were not as severely decompensated as those in Group I. Those in Group III showed either doubtful or no improvement and include the patients with well compensated heart disease or with symptoms due to neuroses.

The results are shown in Table I. The data recorded are the initial level of the metabolic rate and the change in the rate as improvement occurred. In all but two patients the metabolic rate was 10 per cent or more above the calculated normal, when congestive failure was present, and tended to decline with improvement. The highest metabolic rates were found in Group I, where they ranged between 15 and 60 per cent above normal, with an average of 32 per cent above normal. The greatest change in rate with improvement in the clinical state was noted in this group, the average decrease being 22 per cent and the range between 5 and 39 per cent. The patients in Group II showed smaller but qualitatively similar changes. In Group III the basal metabolic rates were, with one exception, within the normal range and no striking variations were observed over periods of a week or longer in the hospital. These observations are in agreement with those reported by previous investigators.

Among the factors that may be considered as conceivably responsible for the increased oxygen consumption in cardiac failure are:

1. Fever

2. Psychic disturbances such as fear or tenseness

3. Altered activity of the thyroid gland

4. An enlarged capillary bed secondary to increased venous pressure

5. Increased work of the respiratory muscles 
TABLE I

The basal metabolic rate at the beginning of observation and the changes in metabolism and $\frac{\text { Ventilation }}{V \text { ital capacity }}$ with improvement *

\begin{tabular}{|c|c|c|c|c|}
\hline & Name & $\begin{array}{c}\text { Initial } \\
\text { level of } \\
\text { basal } \\
\text { metabolic } \\
\text { rate. }\end{array}$ & $\begin{array}{c}\text { Change in } \\
\text { basal } \\
\text { metabolic } \\
\text { rate with } \\
\text { improve- } \\
\text { ment }\end{array}$ & $\begin{array}{c}\text { Change in } \\
\text { Ventilation } \\
\text { Vital capacity } \\
\text { with improve- } \\
\text { ment }\end{array}$ \\
\hline \multirow[t]{2}{*}{$\begin{array}{l}\text { Group I } \\
\text { Moderate or } \\
\text { severe car- } \\
\text { diac failure, } \\
\text { marked im- } \\
\text { provement }\end{array}$} & $\begin{array}{l}\text { M.T. } \\
\text { Y.D. } \\
\text { P.F. } \\
\text { M.L. } \\
\text { A.M. } \\
\text { A.M. } \\
\text { J.E. } \\
\text { E.P. } \\
\text { J.K. } \\
\text { I.M. } \\
\text { W.C. } \\
\text { F.B. } \\
\text { A.E. } \\
\text { G.M. }\end{array}$ & $\begin{array}{c}\text { per cent } \\
+60 \\
+37 \\
+52 \\
+34 \\
+37 \\
+35 \\
+15 \\
+30 \\
+32 \\
+26 \\
+24 \\
+30 \\
+15 \\
+23\end{array}$ & $\begin{array}{c}\text { per cent } \\
-39 \\
-30 \\
-30 \\
-28 \\
-28 \\
-18 \\
-26 \\
-22 \\
-20 \\
-20 \\
=15 \\
=15 \\
=5 \\
-5\end{array}$ & $\begin{array}{l}-4.2 \\
-1.6 \\
-1.0 \\
-2.0 \\
-1.9 \\
-0.6 \\
-0.9 \\
-1.4 \\
-1.2 \\
-1.0 \\
-1.0 \\
-4.0 \\
-1.1 \\
-0.2\end{array}$ \\
\hline & Average & +32 & -22 & -1.6 \\
\hline \multirow[t]{2}{*}{$\begin{array}{l}\text { Group II } \\
\text { Slight im- } \\
\text { provement. } \\
\text { Slight cardiac } \\
\text { failure }\end{array}$} & $\begin{array}{l}\text { C.S. } \\
\text { R.M. } \\
\text { M.B. } \\
\text { P.F. } \\
\text { A.C. } \\
\text { L.M. }\end{array}$ & $\begin{array}{l}+55 \\
+15 \\
+18 \\
+10 \\
+5 \\
+16\end{array}$ & $\begin{array}{r}-30 \\
-20 \\
-20 \\
-10 \\
0 \\
0\end{array}$ & $\begin{array}{l}-2.0 \\
-0.2 \\
-0.5 \\
-0.6 \\
-0.4 \\
-0.4 \\
\end{array}$ \\
\hline & Average & +20 & -15 & -0.7 \\
\hline $\begin{array}{l}\text { Group III } \\
\text { No improve- } \\
\text { ment. No } \\
\text { cardiac fail- } \\
\text { ure }\end{array}$ & $\begin{array}{l}\text { J.M. } \\
\text { R.O. } \\
\text { S.F. } \\
\text { M.W. } \\
\text { E.O. } \\
\text { U.R. } \\
\text { Average }\end{array}$ & $\begin{array}{l}-3 \\
-10 \\
+5 \\
+6 \\
+23 \\
+2 \\
+5\end{array}$ & $\begin{array}{r}+6 \\
0 \\
0 \\
0 \\
-4 \\
0 \\
0\end{array}$ & $\begin{array}{l}-0.3 \\
-1.0 \\
+0.5 \\
-0.6 \\
+2.3 \\
+0.2 \\
+0.5\end{array}$ \\
\hline
\end{tabular}

* The degree of the decline in metabolism and in respiratory effort appear to vary directly with the extent of improvement.

$\dagger$ Second admission.

6. Increased oxygen consumption of the heart itself.

The first factor need not be considered in the present study since none of our subjects had fever at the time of observation. The five other factors suggested may be considered separately.

\section{Psychic disturbances}

Emotional disturbances will vary in different individuals and are to some extent unavoidable. We tried to minimize them by using well trained persons, many of whom had been subjects for respiratory observations on previous admissions. The most obviously neurotic patients were found in Group III, but in this group the metabolic rates remained fairly constant, so that we felt that variations due to psychic factors could not account for the striking changes observed in the other groups.

\section{The factor of altered activity of the thyroid gland}

Lev and Hamburger (4) suggested that an altered activity of the thyroid gland secondary to circulatory changes may be responsible for the increased metabolism in patients with cardiac disease. The known circulatory changes in congestive failure are a prolongation of the circulation time, and an increase in venous pressure. An attempt was made to produce similar changes in the neck veins of dogs either by suspending the animal upside down or by applying a pressure cuff inflated to $40 \mathrm{~mm}$. $\mathrm{Hg}$. about the neck below the level of the thyroid gland. In several animals so treated over a period of 4 or 5 hours no significant variations in oxygen consumption were observed.

A favorable response to iodine has been considered a good index of the presence of thyrotoxicosis. One patient with severe congestive failure and a basal metabolic level of +35 did not respond to iodine administration over a period of two weeks-although on the usual cardiac regime he had repeatedly shown marked improvement and a decline in basal metabolic rate to a level of about +10 per cent. This evidence, though meager, does not favor the hypothesis of a transient hyperthyroidism in cardiac failure.

\section{The effect of an enlarged capillary bed}

Could the increased oxygen consumption observed in congestive failure be due to the increased venous pressure per se? Such a change might conceivably follow the enlarging of the area of contact between tissues and blood as a result of dilatation of the venules and capillaries. Attempts were made to test this hypothesis by measuring the oxygen consumption in a limb or isolated muscle under varying conditions of venous pressure. In some experiments an elevation in metabolism was noted, accompanied by either an increase or decrease in blood flow. In others the opposite effect was found. There were many 
technical difficulties and no procedure was free from theoretical objections, so that we cannot draw any conclusions from our data.

Observations of interest in this connection have been made in four patients with increased venous pressure, peripheral edema, ascites and hepatomegaly, the results of obstruction to the entrance of blood into the heart. The obstruction in one case was due to a mediastinal tumor, and in the other three to pericarditis (concretio cordis). Dyspnea at rest was not a prominent symptom and the hearts were either normal in size or only slightly enlarged. The levels of the basal metabolic rates in these cases were respectively +9 per cent, -9 per cent, -11 per cent and -15 per cent. In the last subject following resection of a portion of the pericardium the venous pressure declined from a level of 400 to $200 \mathrm{~mm} . \mathrm{H}_{2} \mathrm{O}$ without any accompanying change in oxygen consumption. This evidence suggests that increased venous pressure of itself cannot be responsible for elevation of the metabolic rate.

\section{The factor of increased work of respiratory muscles}

Peabody, Meyer and DuBois made the first satisfactory determinations of the basal metabolic rate in patients with heart disease, and noted an increase in oxygen consumption in dyspneic patients (1). They stated, " Dyspneic patients must do an increased amount of work in their labored breathing but it is doubtful if this would account

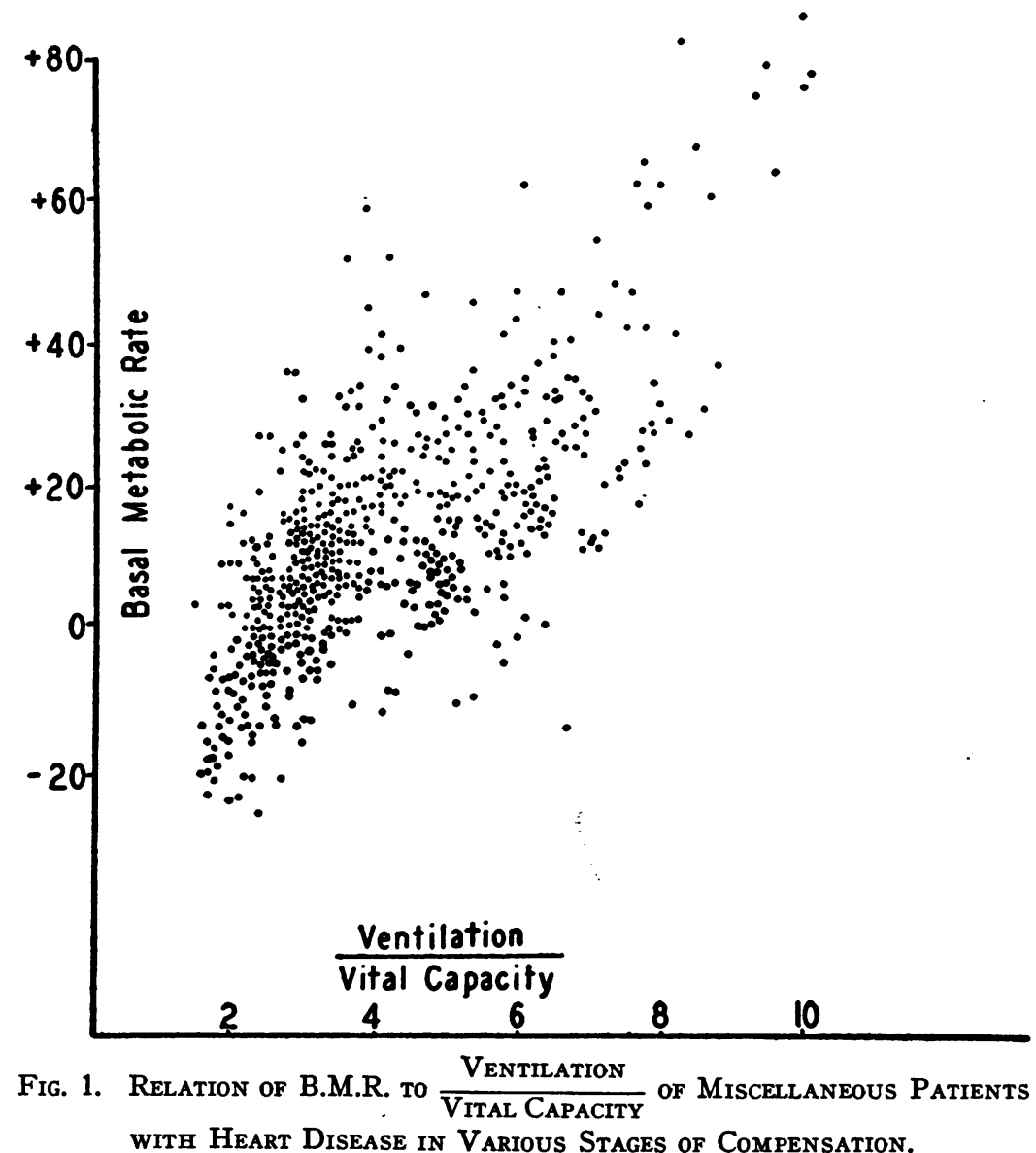

This chart represents repeated measurements on 25 patients with congestive failure. The basal metabolic rate is plotted against respiratory effort as measured by the ratio $\frac{\text { Ventilation }}{\text { Vital capacity }}$. Although there is considerable scattering of points there is a correlation between the functions studied. 
for an increase of more than 10 per cent." Peabody, Wentworth and Barker stressed the importance of the reduced vital capacity and the increased ventilation in heart failure and recognized their relation to dyspnea and the increased oxygen consumption (2). These ideas were emphasized with the volume of air breathed and inversely as the vital capacity.

In normal people under basal conditions the values for $\frac{\text { Ventilation }}{\text { Vital capacity }}$ have been found to be usually less than 2 . In patients with heart dis-

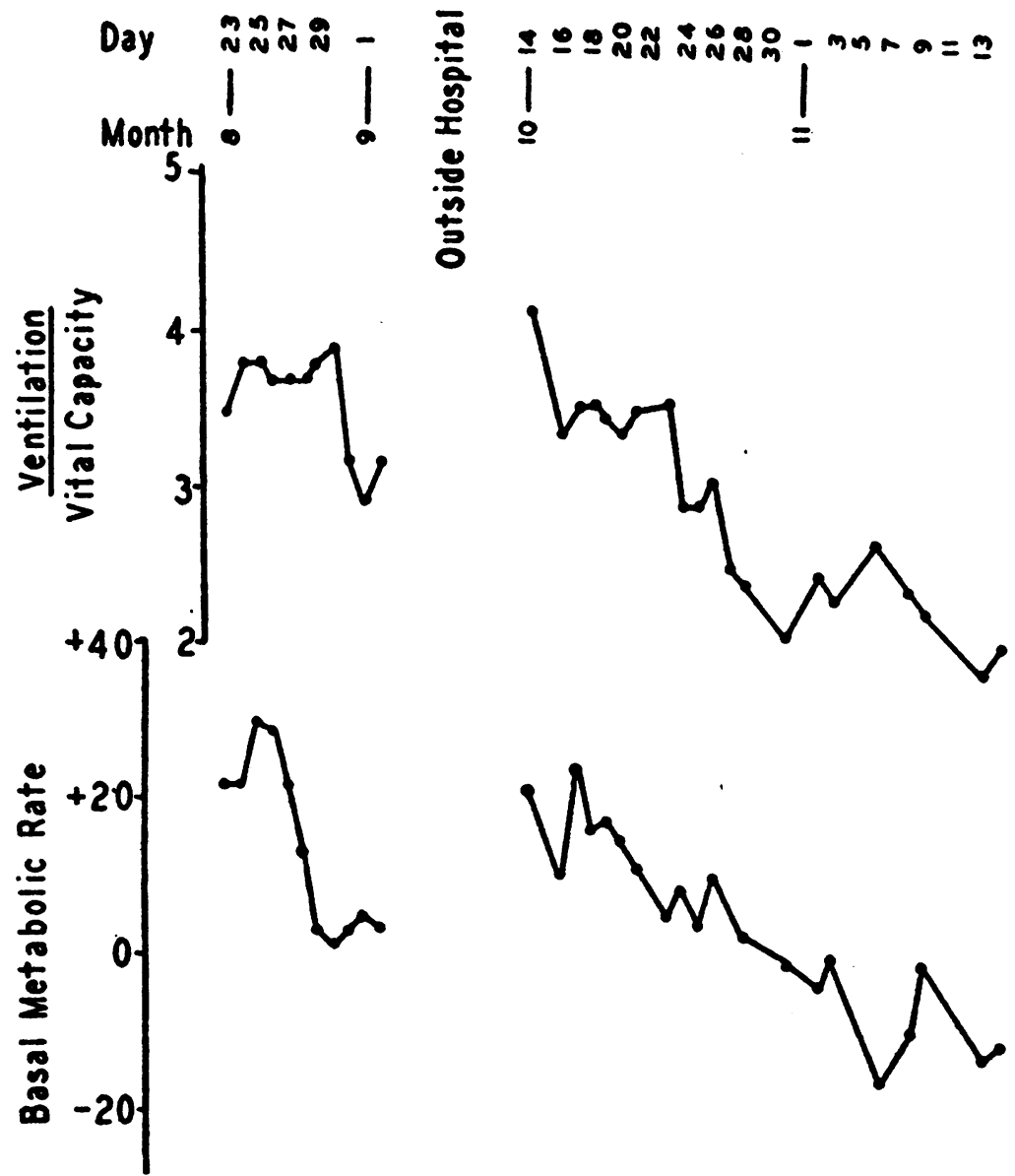

Fig. 2. Changes in B.M.R. and $\frac{\text { Ventilation }}{\text { Vital Capacity }}$ in Patient A.M. during Treatment for Congestive Failure.

This illustrates the rough parallelism between changes in the basal metabolic rate and the amount of dyspnea as represented by the ratio of $\frac{\text { Ventilation }}{\text { Vital capacity }}$ during recovery from congestive failure on two occasions.

by Harrison and his coworkers (5), who found the degree of dyspnea to be roughly proportional to the expression $\frac{\text { Ventilation (in liters per minute) }}{\text { Vital capacity (in liters) }}$ This ratio may be used to represent also the work performed by the muscles of respiration which, other things being equal, will tend to vary directly ease values ranging up to 10 have been noted. In Figure 1 are represented more than 300 observations of the basal metabolic rate and the ratio Ventilation in 25 patients in various stages of Vital capacity cardiac failure. The points show considerable scattering. There is, however, an apparent cor- 


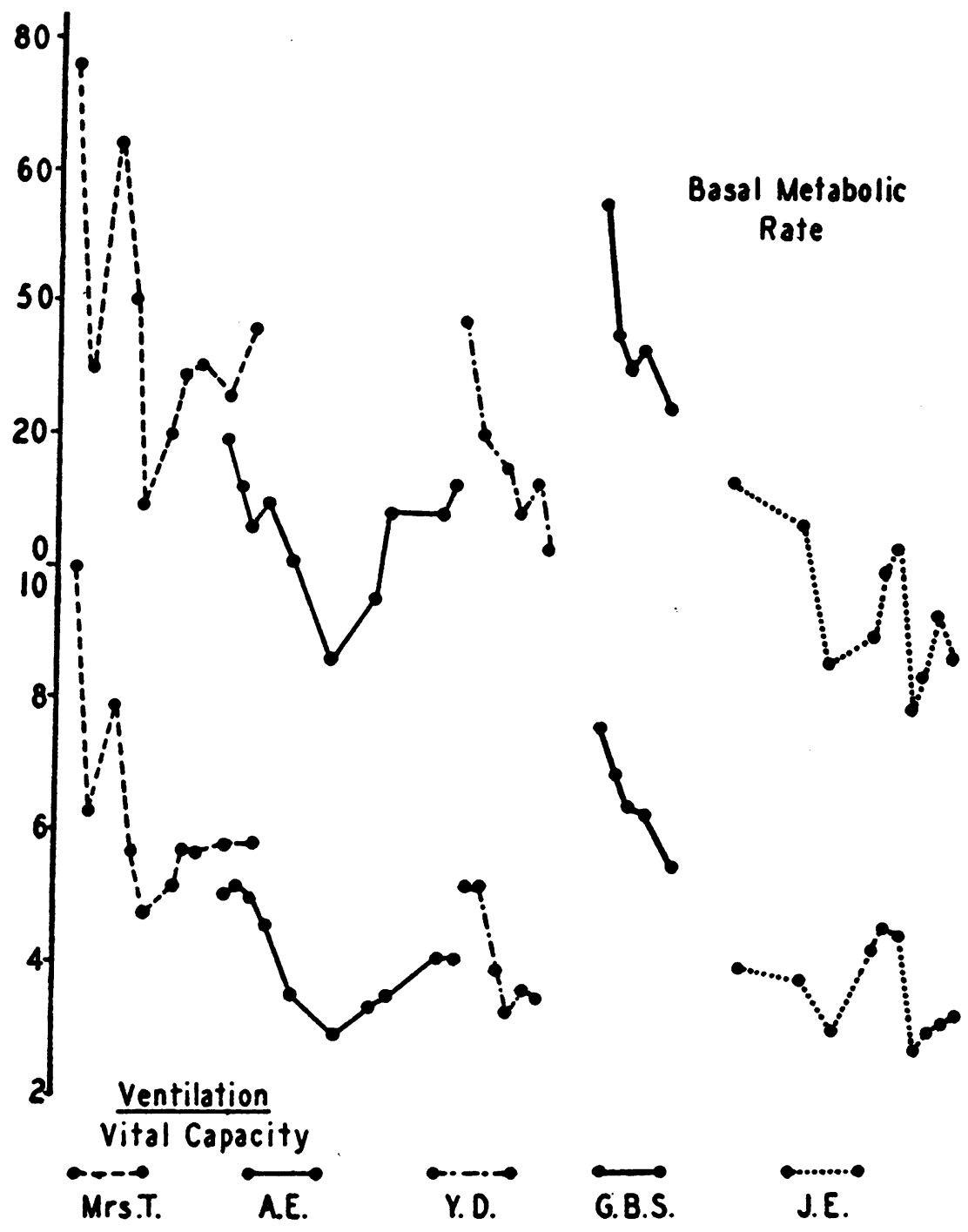

Fig. 3. Changes in B.M.R. and $\frac{\text { Ventilation }}{\text { Vital Capacity }}$ in Cardiac Cases under TREATMENT.

This chart illustrates the general parallelism between variations in the basal metabolic rate and the ratio of $\frac{\text { Ventilation }}{\text { Vital capacity }}$ in five patients during recovery from congestive failure.

relation between the two functions studied, particularly when the ratio for the $\frac{\text { Ventilation }}{\text { Vital capacity }}$ exceeds 6 . The data on two patients with congestive failure associated in one with mild thyrotoxicosis, and in the other with postoperative myxedema, gave values for these individuals that fell along the upper and lower limits of the graph, respectively. The numerical changes in the ratio $\frac{\text { Ventilation }}{\text { Vital capacity }}$ in the group of patients studied are recorded in the last column of Table I. There was a decline in this function in all persons who showed definite improvement. The diminution was greatest in Group I, in which as we have noted, failure was most severe, improvement well defined, and reduction in oxygen consumption most marked. 


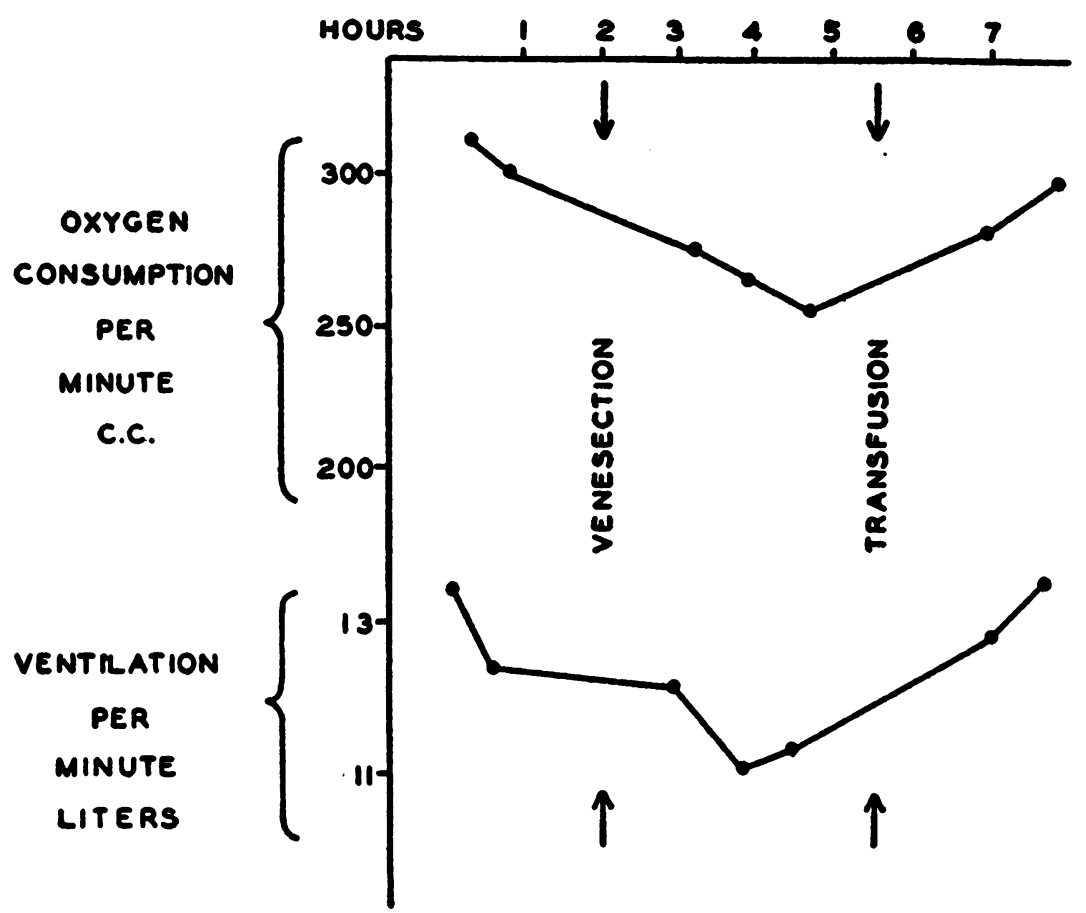

Fig. 4. Subject F. B. Effect of Venesection and Transfusion on MetabOLISM AND Ventilation.

After venesection of $500 \mathrm{cc}$. of blood there was a fall in the oxygen consumption and in the ventilation of the patient. After the blood was reinfused the oxygen consumption and ventilation both rose.

The correlation noted above is more striking in the graph for the individual subject. In charting the serial changes as the patient improves the tendency to parallel variation is again brought out. In Figure 2 are represented the data on Patient A. M. during two periods of hospitalization, and in Figure 3 studies over shorter periods on other persons with heart disease. At times the metabolic rate and the ratio for the $\frac{\text { Ventilation }}{\text { Vital capacity }}$ tend to vary independently, or one may lag behind the other, indicating that there are other factors to be considered.

Sudden and parallel changes in oxygen consumption and total ventilation were observed following abdominal paracentesis in a patient with rheumatic heart disease and massive ascites (Table II). About 4 liters of fluid were removed. Observations were made just before the operation, immediately afterward, 6 hours and 24 hours later. There was an immediate drop of 28 per cent in ventilation and 23 per cent in the oxygen consumption, which was fairly well sus-
TABLE II

Effect of abdominal paracentesis on metabolism and ventilation.

(Subject A. T.: Rheumatic heart disease, congestive failure with ascites. Four liters of fluid removed at one sitting.)

\begin{tabular}{|c|c|c|c|}
\hline & $\begin{array}{c}\text { Before } \\
\text { para- } \\
\text { centesis }\end{array}$ & After paracentesis & $\begin{array}{l}\text { Per } \\
\text { cent } \\
\text { change }\end{array}$ \\
\hline Vital capacity, $c c$. . & 1850 & $*$ & $?$ \\
\hline $\begin{array}{l}\text { Ventilation, liters } \\
\text { per minute...... }\end{array}$ & 10.7 & $\begin{array}{l}\text { 7.7 Immediately after } \\
\text { 6.3 Six hours later } \\
\text { 7.4 Next day }\end{array}$ & $\begin{array}{l}-28 \\
-41 \\
-31\end{array}$ \\
\hline $\begin{array}{l}\text { Oxygen consump- } \\
\text { tion, } c c \text {. per min- } \\
\text { ute........... }\end{array}$ & 202 & $\begin{array}{l}157 \text { Immediately after } \\
161 \text { Six hours later } \\
169 \text { Next day }\end{array}$ & $\begin{array}{l}-23 \\
-20 \\
-16\end{array}$ \\
\hline
\end{tabular}

* On account of pain at the site of incision the vital capacity after operation could not be determined.

tained for at least 24 hours. On account of pain at the site of incision the vital capacity after abdominal tapping could not be determined.

The effect of venesection is illustrated graph- 
ically in Figure 4. The initial oxygen consumption was $310 \mathrm{cc}$. per minute. Following the removal of $500 \mathrm{cc}$. of blood there was a drop in the oxygen consumption to $260 \mathrm{cc}$. per minute in a period of two and one half hours. An hour later the blood was reinfused, after which the oxygen consumption rose almost to its original level. The changes in ventilation parallel closely the variations in metabolism. Comparable diminutions in metabolism were observed in 3 other patients in whom venesection was carried out. In only one instance was the blood reinfused. panied by an increase in the rate of oxygen consumption. There have been identified a number of variables among which are the rate and depth of respirations, the level of ventilation and the presence or absence of respiratory obstruction. Loewy (6) reviewed the earlier investigations on this subject. Lev and Hamburger (4) noted a rise of 17.5 per cent in the metabolic rate in one patient during a period of voluntary hyperpnea. Anrep and Hammouda (7) found in panting dogs that the oxygen consumption increased in proportion to the total ventilation and concluded that the

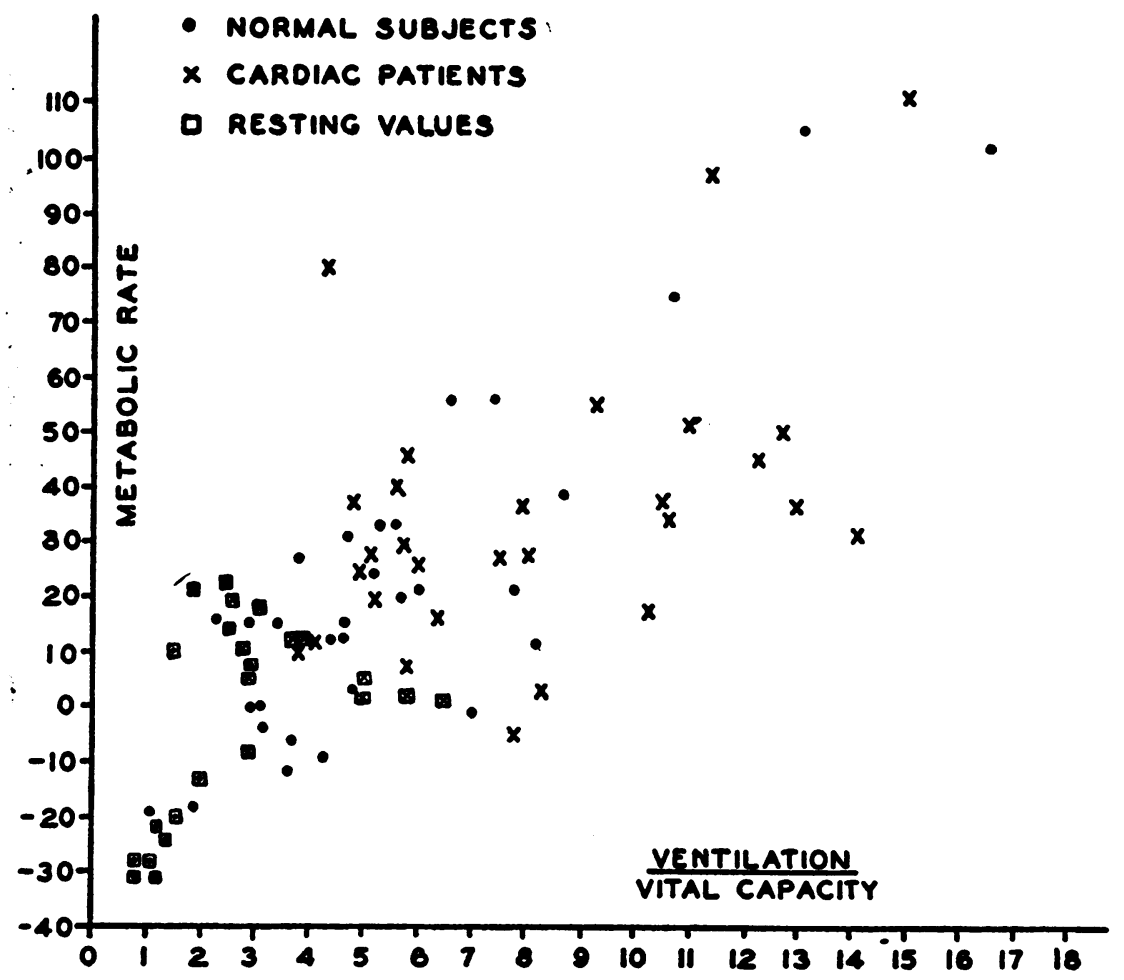

Fig. 5. The Effect of Voluntary Overventilation on the Metabolic Rate.

Seven normal individuals and eight patients with cardiac disease were studied. The points that are squared represent resting values. The others were obtained during voluntary overventilation. The chart illustrates the extent to which an increase of ventilation can raise the metabolic rate.

The data so far presented indicate that there is a qualitative, and to some extent quantitative, correlation between the metabolism and the work of the respiratory muscles (as measured by the expression $\frac{\text { Ventilation }}{\text { Vital capacity }}$.

There are several reports in the literature indicating that an increase in the ventilation is accom- rise was due to the increased work of respiration.

Marked elevations in metabolism were observed in subjects made to overventilate either voluntarily or by breathing carbon dioxide. Figure 5 presents composite results in 7 normal people and 8 patients with cardiac disease during voluntary hyperpnea. No attempt was made to regulate the rate or depth of breathing. The total period 

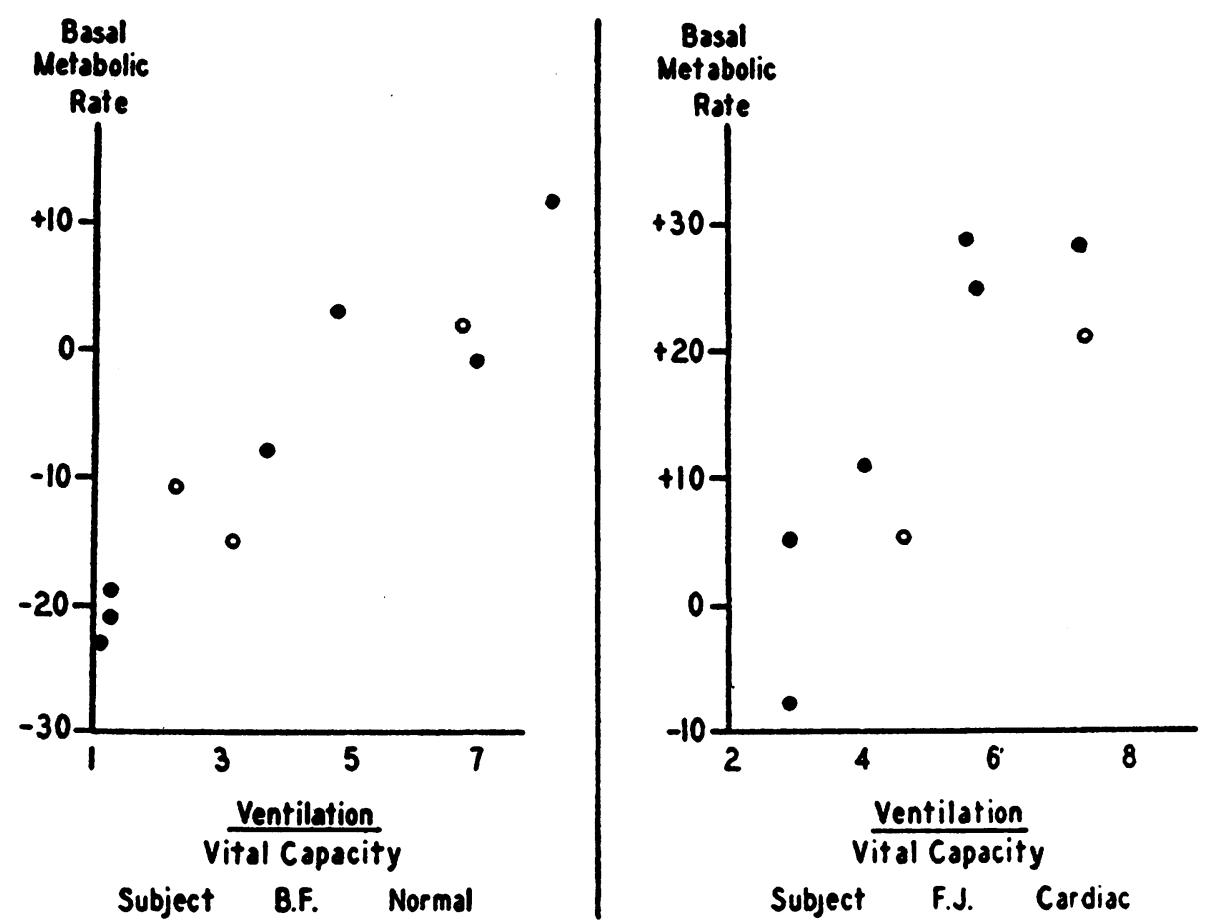

Fig. 6. Changes in Metabolism with Overventilation.

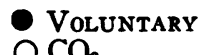

The figure at the left represents the effects of changes in ventilation on the metabolic rate of a normal subject. The three black circles in the left lower corner are resting values. Both voluntary overventilation (black circles) and involuntary overventilation produced by carbon dioxide (hollow circles) resulted in a well marked increase in metabolic rate. Similar results as illustrated by the figure on the right were obtained in a patient with heart disease.

of hyperpnea varied in different individuals between 3 and 6 minutes, depending on the rapidity with which fatigue occurred. These variables are in part reflected in the wide scattering of the points. Nevertheless, there is an apparent correlation between the ratio $\frac{\text { Ventilation }}{\text { Vital capacity }}$ and the metabolic rate. The elevations in metabolism due to voluntary overventilation are comparable to, though in general a little lower than those due to spontaneous dyspnea (Fig. 1).

The data in two typical experiments comparing normal respiration, voluntary hyperpnea and carbon dioxide overventilation are shown graphically in Figure 6. All observations were made at one sitting with 15 to 30 minute intervals between determinations. For a comparable increase in ventilation the elevation in metabolic rate seems more marked with voluntary than with involuntary hyperpnea. This is in agreement with the findings of Liljestrand cited by Loewy (6).
The most marked effect with carbon dioxide overventilation was shown by F. B. (Table III).

TABLE III

The effect of carbon dioxide overventilation on the oxygen consumption

(Subject F. B.: Syphilitic heart disease; vital capacity, $1750 \mathrm{cc}$.)

\begin{tabular}{|c|c|c|c|c|c|}
\hline Period ........... & 1 & 2 & 3 & 4 & 5 \\
\hline Condition........ & $\begin{array}{l}\text { Normal } \\
\text { breath- } \\
\text { ing }\end{array}$ & $\begin{array}{c}\text { Normal } \\
\text { breath- } \\
\text { ing }\end{array}$ & $\begin{array}{l}\text { Breath- } \\
\text { ing } 2 \text { per } \\
\text { cent CO. }\end{array}$ & $\begin{array}{l}\text { Breath- } \\
\text { ing } 3 \text { per } \\
\text { cent CO. }\end{array}$ & $\begin{array}{l}\text { Breath- } \\
\text { ing } 5 \text { per } \\
\text { cent CO2 }\end{array}$ \\
\hline $\begin{array}{l}\text { Duration of } \\
\text { breathing, mix- } \\
\text { ufes. } \\
\text { Ventiling.... }\end{array}$ & 6 & 6 & 4 & 3 & 2 \\
\hline $\begin{array}{c}\text { per mimute...... } \\
\text { Ventilation }\end{array}$ & 8.4 & 8.1 & 11.7 & 24.7 & 24.3 \\
\hline $\begin{array}{l}\text { Vital capacity } \cdots . \\
\text { Oxygen consump- }\end{array}$ & 4.8 & 4.7 & 6.7 & 14.1 & 13.3 \\
\hline $\begin{array}{l}\text { tion, } \\
\text { minute........... }\end{array}$ & 253 & 258 & 265 & 501 & 477 \\
\hline $\begin{array}{c}\text { Pulse rate, per } \\
\text { minute. } . . . . . .\end{array}$ & 90 & 88 & 104 & 104 & 104 \\
\hline
\end{tabular}

Note an increase in metabolism of about 100 per cent in Period 4, and 90 per cent in Period 5. 
The oxygen consumption almost doubled with a threefold increase in ventilation.

The effect of depressing the respiration with morphine was studied in six patients. In every dyspneic patient there was a well marked decline in ventilation and a slight or moderate decrease in metabolic rate, the magnitude of the change in both ventilation and metabolic rate varying with the initial level of $\frac{\text { Ventilation }}{\text { Vital capacity }}$. The results in two typical experiments are recorded in Table IV. Patient A. M., with a slightly elevated Ventilation

Vital capacity oxygen consumption beyond the limits of error of the method. Subject T. M. had marked dyspnea, an initial $\frac{\text { Ventilation }}{\text { Vital capacity }}$ quotient of 10 and

TABLE IV

Effect of morphine on oxygen consumption and $\frac{\text { Ventilation }}{\text { Vital capacity }}$

( $A$. Subject A. M.: Luetic heart disease, well compensated, showing very slight change in metabolism as result of a 28 per cent decrease in ventilation when the initial $\frac{\text { Ventilation }}{\text { Vital capacity }}$ is slightly elevated.)

\begin{tabular}{|c|c|c|c|c|}
\hline Condition & $\begin{array}{l}\text { Normal } \\
\text { breath- } \\
\text { ing }\end{array}$ & $\begin{array}{l}45 \text { min- } \\
\text { utes after } \\
\text { morphine }\end{array}$ & $\begin{array}{c}1 \text { hour } \\
\text { after } \\
\text { morphine }\end{array} \mid$ & $\begin{array}{l}11 / 2 \text { hours } \\
\text { after } \\
\text { morphine. } \\
\text { Breathing } \\
3 \text { per cent } \\
\text { CO? }\end{array}$ \\
\hline $\begin{array}{l}\text { Oxygen consump- } \\
\text { tion, } c c \text {. per min- } \\
\text { ute . . . . . . . . . } \\
\text { Ventilation } \\
\text { Vital capacity }\end{array}$ & $\begin{array}{r}244 \\
2.9\end{array}$ & $\begin{array}{l}242 \\
2.1\end{array}$ & $\begin{array}{r}236 \\
2.0\end{array}$ & $\begin{array}{r}262 \\
3.9\end{array}$ \\
\hline
\end{tabular}

(B. Subject T. M.: Hypertensive heart disease-severe dyspnea, showing marked reduction in metabolism with 36 per cent reduction in ventilation when the initial $\frac{\text { Ventilation }}{\text { Vital capacity }}$ is markedly elevated.)

\begin{tabular}{c|c|c|c}
\hline \hline Condition & $\begin{array}{c}\text { Normal } \\
\text { breathing }\end{array}$ & $\begin{array}{c}45 \text { minutes } \\
\text { after } \\
\text { morphine }\end{array}$ & $\begin{array}{c}\text { 1 hour after } \\
\text { morphine. } \\
\text { 3reathing } \\
\text { per cent co, }\end{array}$ \\
\hline $\begin{array}{c}\text { Oxygen consump- } \\
\text { tion, cc. per min- } \\
\text { ute................ }\end{array}$ & 265 & 202 & 254 \\
$\begin{array}{c}\text { Ventilation } \\
\text { Vital capacity }\end{array}$ & 10.0 & 6.4 & 7.7 \\
\hline
\end{tabular}

an oxygen usage of $265 \mathrm{cc}$. per minute. Fortyfive minutes after the subcutaneous injection of 0.02 gram of morphine the ratio had declined to 6.4 and the oxygen consumption to $202 \mathrm{cc}$. That this is not wholly due to the hypnotic effect of morphine is indicated by the fact that subsequently when the breathing of this patient was stimulated by carbon dioxide the oxygen consumption increased to $254 \mathrm{cc}$. per minute. Furthermore, non-dyspneic patients (as A. M.) showed very little or no change in metabolic rate following morphine. ${ }^{1}$

These observations demonstrate that the increased work of respiration in dyspneic patients is an important factor in the production of their elevated oxygen consumption.

\section{Oxygen consumption of the heart}

In evaluating the rôle played by the heart in the increased oxygen consumption in cardiac disease we are forced to depend largely on indirect evidence. The assumption that the heart plays such a rôle rests on two general propositionsfirst, that the failing heart is dilated; and second, that a dilated heart uses more oxygen in doing a given amount of work than a normal heart. The first has been amply demonstrated in the experimental animal by Patterson, Piper and Starling (8) and by Rohde (9), and in man by Stewart and Cohn (10). The second has been established by the work of. Evans and Matsuoka (11) and Starling and Visscher (12). In the heart-lung preparation the latter authors found that the oxygen used by the heart is dependent on the diastolic volume, i.e., the degree of dilatation. As the heart tires it dilates and although the work remains constant the energy expended in doing it may be increased by as much as 60 per cent.

Harrison, Friedman and Resnik (13) studied the effect on the heart of the dog of certain injurious agents, namely, anoxemia, potassium chloride and chloroform. They obtained data for the calculation of the total metabolism, the cardiac oxygen consumption, and the cardiac work. As

1 The observations on the effect of morphine on the ventilation suggest the possibility that in a patient with congestive failure and suspected hyperthyroidism because of increased oxygen consumption, the response to morphine may offer a means of determining the relative importance of thyroid and respiratory activity. 
cardiac failure occurred there was observed in all experiments an increase in the amount of oxygen used by the heart. This was noted even in the presence of a marked diminution in total oxygen consumption and in total cardiac work.

On the basis of these investigations there is little doubt that the heart does contribute to the elevated metabolism in cardiac disease. The question is whether its share is large or small. Starling and Evans (14), in the heart-lung preparation, found the oxygen consumption of the dog's heart to average $3.2 \mathrm{cc}$. per gram per hour. Comparable values were obtained by Harrison, Friedman and Resnik (13), in dogs with the chest and pericardium open. The procedure they employed causes considerable surgical shock. Because the lowered blood pressure and decreased cardiac output in shock results in diminished cardiac work, the data so obtained are not strictly applicable to animals in good condition. Using a new device these latter observers were able to determine the metabolism of the heart in animals with the chest intact. The average value for the cardiac oxygen consumption of morphinized dogs was found to be 5.3 cc. per gram per hour and about 11 per cent of the oxygen consumption of the whole animal. When the heart was made to overwork either by increasing the cardiac output (infusion of saline or blood) or by elevating the blood pressure (adrenalin, cutting the vagi, clamping the carotid arteries) its oxygen consumption per gram of muscle increased as much as 100 per cent. Under periods of maximum stress the oxygen consumption of the heart amounted to as much as 30 per cent of the total metabolism.

Clinically however, no such changes in cardiac work occur in congestive failure, for neither the cardiac output (15) nor the blood pressure vary very widely, nor in any consistent direction. While the total work of the heart does not change much, the energy expended in accomplishing it is greatly increased if the observations in the experimental animal with dilated and failing hearts are applicable to man. That this increased cost of performing work may be significant can best be illustrated by a concrete example. Let us make three assumptions:

1 . The average oxygen consumption of the normal human heart is, like that of the dog's heart, 0.09 cc. per gram per minute.
2. The hypertrophied heart uses as much oxygen per gram as does the normal.

3. As the heart dilates and fails its oxygen consumption increases about 40 per cent. (This corresponds with the changes observed by Starling and Visscher in the heart-lung preparation, and by Harrison, et al., in the intact dog.)

If under these assumed conditions a patient with a normal oxygen consumption of $200 \mathrm{cc}$. per minute and with a heart weighing 250 grams, should develop cardiac hypertrophy (heart weight 500 grams), and later decompensation, then the total oxygen consumption, and that of the heart might be as shown in Table $\mathrm{V}$.

TABLE V

Oxygen consumption in a hypothetical case

\begin{tabular}{|c|c|c|c|c|c|c|}
\hline $\begin{array}{l}\text { Condition } \\
\text { of heart }\end{array}$ & Dyspnea & $\begin{array}{l}\text { Heart } \\
\text { weight }\end{array}$ & $\begin{array}{l}\mathrm{O}_{2} \text { con- } \\
\text { sump- } \\
\text { tion of } \\
\text { heart }\end{array}$ & $\begin{array}{l}\mathrm{O}_{2} \text { con- } \\
\text { sump- } \\
\text { tion of } \\
\text { the rest } \\
\text { of the } \\
\text { body }\end{array}$ & $\begin{array}{l}\text { Total } \\
\text { O,con- } \\
\text { sumpp- } \\
\text { tion }\end{array}$ & $\begin{array}{l}\text { Basal } \\
\text { meta- } \\
\text { bolic } \\
\text { rate }\end{array}$ \\
\hline \multirow{4}{*}{$\begin{array}{l}\text { Normal....... } \\
\text { Compensated, } \\
\text { hypertrophied.. } \\
\text { Decompensated, } \\
\text { hypertrophied.. } \\
\text { Decompensated, } \\
\text { hypertrophied.. }\end{array}$} & Absent & $\begin{array}{c}\text { grams } \\
250\end{array}$ & $\left|\begin{array}{c}c c . \text { per } \\
\text { minute } \\
22.5\end{array}\right|$ & $\begin{array}{c}\text { cc. per } \\
\text { minute } \\
177.5\end{array}$ & $\mid \begin{array}{l}c c . \text { per } \\
\text { minute } \\
200\end{array}$ & \\
\hline & Absent & 500 & 45 & 177.5 & 222.5 & +11 \\
\hline & Absent & 500 & 63 & 177.5 & 240.5 & +20 \\
\hline & Present & 500 & 63 & $227.5^{*}$ & 290.5 & +45 \\
\hline
\end{tabular}

* Including effect of dyspnea. An increase of 25 per cent in oxygen consumption due to respiratory effort in severe dyspnea $\left[\frac{\text { Ventilation }}{\text { Vital capacity }}\right.$ ratio $\left.=6-8\right]$ is consistent with the data represented in Figure 5.

In Table $\mathrm{V}$, which may be taken as representative of severe congestive failure, the increased cardiac oxygen consumption accounts for an increment of 20 per cent in the total metabolism.

\section{SUM MARY}

The effect of therapy upon the oxygen consumption of twenty-five patients with heart disease was observed. It was noted that in general those with the most marked evidence of congestive failure had the greatest elevation of metabolic rate, and showed the most pronounced decline in oxygen consumption with improvement. There was a rather striking parallelism between changes in the degree of dyspnea as measured by the ratio 
Ventilation

Vital capacity

and the variations in the metabolic

rate. The effect upon the oxygen consumption of increased ventilation produced both voluntarily and by the inhalation of carbon dioxide was measured in both normal subjects and in patients with heart disease. In general, it was found that an increase of the ratio $\frac{\text { Ventilation }}{\text { Vital capacity }}$ was associated with a rise in the oxygen consumption of sufficient magnitude to account for a large portion of the elevation in metabolic rate found in patients with cardiac dyspnea. Measures, such as venesection, paracentesis and the administration of morphine, which lower the ratio $\frac{\text { Ventilation }}{\text { Vital capacity' }}$ were usually effective in reducing the oxygen consumption of dyspneic patients. In one subject the re-infusion of blood that had been removed a short time previously caused the ventilation and oxygen consumption to rise to about their preexisting values.

In addition to the effect of labored breathing, if it can be assumed that observations made upon the failing heart of the dog can be applied to the diseased heart of man, then calculations indicate that the oxygen consumption of the heart also may be an important factor in the elevation of the basal metabolic rate occurring in patients with congestive failure.

\section{DISCUSSION}

The above observations indicate that the increased work of the respiratory muscles associated with cardiac dyspnea adds another load to an already overburdened heart. This factor of respiratory effort assumes greater importance as cardiac failure becomes worse, for the ventilation tends to rise and the vital capacity to fall, thus increasing the ratio $\frac{\text { Ventilation }}{\text { Vital capacity }}$ in geometric proportions. Procedures which tend to reduce the ventilation (rest, morphine, venesection, paracentesis) or to increase the vital capacity (paracentesis) are beneficial in part through reduction of the work of breathing.

In advanced congestive failure with severe dyspnea the factor of labored breathing seems to play the most important rôle in elevating the me- tabolism. The increased oxygen consumption of the diseased heart ranks next in importance. Other factors appear to be relatively minor. Of course, in evaluating the significance of an elevated basal metabolic rate in a given patient with cardiac disease the factors of fever, nervousness and thyroid activity must be considered as in any other patient.

\section{CONCLUSIONS}

1. The basal metabolic rate is elevated in many persons with congestive cardiac failure and declines as improvement occurs. The degree of elevation (and decline) tends to parallel the severity of congestive failure (and the extent of improvement).

2. The mechanisms responsible for these changes have been investigated. The increased work of the muscles of respiration appears to be the chief factor; the diminished mechanical efficiency and consequent increased energy expenditure of the diseased heart may also play an important rôle.

The authors acknowledge their indebtedness to Dr. Tinsley R. Harrison for his valuable assistance in the making of these studies.

\section{BIBLIOGRAPHY}

1. Peabody, F. W., Meyer, A. L., and DuBois, E. F., Clinical calorimetry. XVI. The basal metabolism of patients with cardiac and renal disease. Arch. Int. Med., 1916, 17, 980.

2. Peabody, F. W., Wentworth, J. A., and Barker, B. I., Clinical studies on the respiration. V. The basal metabolism and the minute-volume of the respiration of patients with cardiac disease. Arch. Int. Med., 1917, 20, 468

3. Boothby, W. M., and Willius, F. A., The basal metabolic rate in cases of primary cardiac disease. M. Clin. North America, 1925, 8, 1171.

4. Lev, M. W., and Hamburger, W. W., Basal metabolism in organic heart disease. Am. Heart J., 1925-26, 1, 240.

5. Harrison, T. R., Turley, F. C., Jones, E., and Calhoun, J. A., Congestive heart failure. X. The measurement of ventilation as a test of cardiac function. Arch. Int. Med., 1931, 48, 377.

6. Loewy, A., Oppenheimer's Handbuch der Biochemie des Menschens und der Tiere, Jena. 1924-30, vol. 9.

7. Anrep, G. V., and Hammouda, M., Observations on panting. J. Physiol., 1932-33, 77, 16.

8. Patterson, S. W., Piper, H., and Starling, E. H., The regulation of the heart beat. J. Physiol., 1914, 48, 465. 
9. Rohde, E., Stoff wechseluntersuchungen am überlebenden Warmblüterherzen. Ztschr. f. physiol. Chem., 1910, 68, 181.

10. Stewart, H. J., and Cohn, A. E., Studies on the effect of the action of digitalis on the output of blood from the heart. III. Part 1. The effect on the output in normal human hearts. Part 2. The effect on the output of hearts in heart failure with congestion in human beings. J. Clin. Invest., 1932, 11, 917.

11. Evans, C. L., and Matsuoka, Y.. The effect of various mechanical conditions on the gaseous metabolism and efficiency of the mammalian heart. J. Physiol., $1915,49,378$.

12. Starling, E. H., and Visscher, M. B., The regulation of the energy output of the heart. J. Physiol., 1922, 62, 243.

13. Harrison, T. R., Friedman, B., and Resnik, H., Jr., The mechanism of acute experimental heart failure. (To be published.)

14. Starling, E. H., and Evans, C. L., The respiratory exchanges of the heart in the diabetic animal. J. Physiol., 1914-15, 49, 67.

15. Harrison, T. R., Friedman, B., Clark, G., and Resnik, $H$., The cardiac output in relation to cardiac failure. Arch. Int. Med., 1934, 54, 239.

16. Boothby, W. M., and Sandiford, I., Normal values of basal or standard metabolism. A modification of the DuBois standards. Am. J. Physiol., 1929, 90, 290. 